ИЗВЕСТИЯ АКАДЕМИИ НАУК ЭСТОНСКОИ ССР. ТОМ 26 ХИМИЯ * ГЕОЛОГИЯ. 1977, № 3

\title{
РЕВИЗИЯ БРАХИОПОД DАYІАСЕА ИЗ СИЛУРА ПРИБАЛТИКИ
}

Материал о первых двух видах из надсемейства Dayiacea (по Moore, 1965) из силура Прибалтики был опубликован в 1967 г. (Рыбникова, 1967). Находки последующих лет позволяют пополнить список таких брахиопод еще пятью видами, уточнить их систематику и стратиграфическое положение. Этим вопросам и посвящена настоящая статья.

Описанные ниже Dayiacea происходят из двух обнажений и девяти буровых скважин (рис. 1). Стратиграфические подразделения разрезов даны по Д. Кальо (устное сообщение) и Л. Сарву (1973). Экземпляры хранятся в музее Института геологии АН ЭССР под каталоговыми номерами начиная с букв $\mathrm{Br}$.

Автор выражает искреннюю признательность А. Циглеру (A. Ziegler, Chicago), П. Konперу (P. Copper, Sudbury) и М. Бассетту (M. Bassett, Cardiff) за идентификацию изученных здесь брахиопод, Р. Ульст и Л. Гайлите (Рига) за предоставление коллекции силурийских брахиопод из скв. Вентспилс и В. Я. Карпицкому за предоставление такой же коллекции из скв. Эзере.

Рис. 1. Расположение обнажений и буровых скважин. 1,2- обнажения Ундва и Суурнку. Скважины: 3 - Каугатума, 4 Икла, 5 - Вентспилс, 6 - Пилтене, 7 Эзере, 8 - Кункояй, 9 - Видукле, 10 Дубовское, 11 - Калвария.

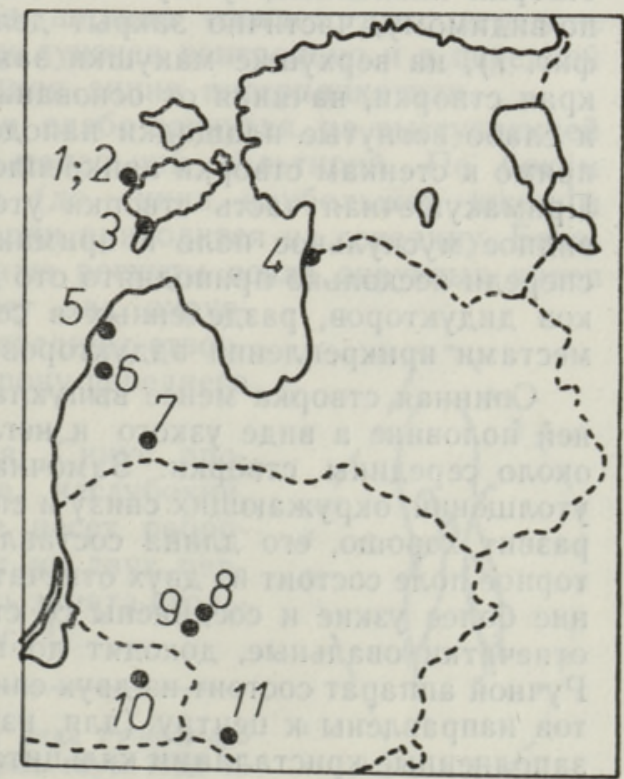


Подотряд Dayioidea Johnson, 1974

Надсемейство Dayiacea Waagen, 1883

Семейство Dayiidae Waagen, 1883

Подсемейство Cyclospirinae Schuchert, 1913

Род Cyclospira Hall et Clarke, 1893

Типовой вид: Orthis bisulcata Emmons, 1842.

Cyclospira circularis sp. nov.

Таб̆л. І, фиг. 1-7.

Голоти п. Раковина $\mathrm{Br} 3753 ;$ Эстонская ССР, скв. Икла, средний лландовери, леммеская пачка райккюлаского горизонта $\left(\mathrm{G}_{3} \mathrm{~L}\right)$, глубина $393,95 \mathrm{M}$.

Д и агноз. Раковина относительно округлого очертания, раздваивающий брюшную створку киль выражен слабо, боковые ребра отсутствуют.

О пис ание. Раковина маленьких размеров, двояковыпуклая, с более высокой брюшной створкой, гладкая. Очертание округленносубквадратическое до субпентагонального. Наибольшая ширина приходится на середину раковины, боковые края округлые, передний край прямой или слабо вогнутый. Смычная линия отогнута у луночек вентрально, а в передней половине раковины дорсально; передняя линия сулькатная.

Брюшная створка умеренно выпуклая, макушка острая и маленькая, загнута свободно, с макушкой спинной створки не соприкасается. Луночки вдоль прямых боков ммакушки узкие. Срединный киль начинается с макушки и изменяется от плоского у середины створки до слабо вогнутого (в поперечном сечении) у переднего края. Боковые части спворки наклонные, у луночек слабо вогнутые. Дельтирий широкий, по-видимому, частично закрыт дельтидиальными пластинами (табл. I, фиг. 7), на верхушке макушки заметен точечный форамен. У заднего края створки, начиная от основания дельтирия, просматриваются узкие и слабо вопнутые площадки наподобие арей. Перед этими площадками прямо к стенкам створки прикреплены маленькие крючкообразные зубы. Примакушечная часть створки утолщена, на дне ее вдавлены сердцевидное мускульное поле и примакушечный желобок. Мускульное поле спереди несколько приподнято ото дна створки, состоит из двух отпечатков дидукторов, разделенных в середине двумя низкими валиками местами прикрепления аддукторов.

Спинная створкка менее выпуклая, чем брюшная; синус развит в задней половине в виде узкого и неглубокого желобка, расширяющегося около середины створки. Замочная пластина раздельная, имеет вид утолщений, окружающих снизу и спереди зубные ямки. Срединный валик развит хорошо, его длина составляет около 4/5 длины спворки. Аддукторное поле состоит из двух отпечатков - внешних и внутренних, последние более узкие и соединены со стенками срединного валика. Внешние отпечатки овальные, доходят до переднего конца срединного валика. Ручной аппарат состоит из двух опиралей, конусы одного или двух оборотов направлены кк центру (для изучения ручного аппарата раковины, заполненные кристаллами кальцита, были растворены). 
Р а 3 м е р ы, $м \mu$

$\begin{array}{ccc}\text { Экземпляр } & \text { Длина } & \text { Наибольшая ширина } \\ \mathrm{Br} 3753 & 4,5 & 4,3 \\ \mathrm{Br} 3754 & 4,3 & 4,3 \\ \mathrm{Br} 3755 & 2,8 & 2,8 \\ \mathrm{~B} r 3756 & 1,6 & 1,5\end{array}$

С р авнен ие. Вид Cyclospira anticostiana (Twenhofel, 1927, p. 213, pl. 21, fig. 15-17) из нижнего лландовери и верхнего ордовика о-ва Антикости отличается от нового вида лишь более вытянутым в длину очертанием раковины и более глубоким желобком на брюшном синусе.

Р аспространение. Эстония, средний лландовери, леммеская пачка райккюлаского горизонта $\left(\mathrm{G}_{3} \mathrm{~L}\right)$.

М естон ахождения. Скв. Икла, интервал глубин 371,65$395,45 \boldsymbol{M}$.

\section{Подсемейство Dayiinae Waagen, 1883}

Род Protozeuga Twenhofel, 1914

Т и по во й вид: Terebratula bicarinata Verneuil, 1848 (=Waldheimia ? mawei Davidson, 1881).

\section{Protozeuga bicarinata (Verneuil, 1848)}

Табл. II, фиг. 1-6; рис. 2

Protozeuga bicarinata: Bassett and Cocks, 1974, p. 32, pl. 9, fig. 3 (полная синоннмика).

Лектотип. Раковина D 647 (University of Orsay, Bassett and Cocks, 1974, pl. 9, fig. 3).

О писание. Раковина маленьких размеров, двояковыпуклая, с более высокой брюшной спворкой. Очертание раковины субпентагональное, вытянутое в длину, наибольшая ширина соответствует середине раковины. Смычная линия отопнута у луночек вентрально и в передней половине раковины дорсально; передняя линия интерпликатная.

Макушка брюшной створки острая, слабо загнутая, на выступающей ее части расположен треугольный маленыкий дельтирий. По бокам макушки развиты длинные луночки (до линии наибольшей ширины створки). Максимальная высота створки приходится на середину. Боковые части створки уплощены или даже вогнуты возле округлых краев луночек. Средняя часть створки несет два округлых ребра, которые начинаются от середины створки и увеличиваются в размерах в сторону переднего края.

Спинная створка слабо выпуклая. Синус просматривается в ее задней половине, неглубокий, расширяющийся кпереди, в середине несет ребровозвышение. Ручной аппарат состоит из двух первых оборотов спиралей, передняя часть занята игольчатыми выступами, югум простой (рис. 2).

Рис. 2. Схема строения ручного аппарата у вида Protozeuga bicarinata. По раковине $\mathrm{Br} 3743$, скв. Калвария, глуб. 775,0 м.

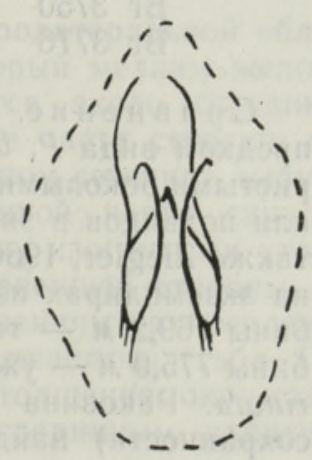


Р а 3 м е р ы, мм

$\begin{array}{ccc}\text { Экземпляр } & \text { Длина } & \text { Наибольшая ширина } \\ \mathrm{Br} 3744 & 3,0 & 2,6 \\ \mathrm{Br} 3745 & 2,5 & 2,3 \\ \mathrm{Br} 3746 & 2,5 & 1,9 \\ \mathrm{Br} 3747 & 2,4 & 1,9 \\ \mathrm{Br} 3748 & 1,9 & 1,6 \\ \mathrm{Br} 3775 & 2,6 & 2,2\end{array}$

3 а меч а ни е. Описанные экземпляры отнесены к виду Protozeuga bicarinata специалистами по английскому и готландскому материалу П. Коппером и М. Бассеттом.

$\mathrm{P}$ а сп р ост р а нени е. Литва, венлок, яагарахуский $\left(\mathrm{J}_{2}\right)$ и яаниский $\left(\mathrm{J}_{1}\right)$ горизонты.

Местонахождения. Скв. Кальвария, интервал глубин 710,7$775,0 \mathrm{M}$.

\section{Protozeuga carinata sp. nov.}

Табл. II, фиг. $7-9$

Голоти п. Раковина Вr 3749; Эстонская ССР, скв. Икла, венлок, парамаяская пачка яаниского горизонта $\left(\mathrm{J}_{1} \mathrm{P}\right)$, глубина 240,85 м.

Д и а г о з. Раковина со слабо ребристыми боковыми частями.

О п и с а и е. Раковина маленькая, двояковыпуклая, с более высокой брюшной створкой. Внешняя поверхность слабо волнистая (ребристая). Очертание раковины субпентагональное, вытянутое в длину, наибольшая ширина приходится на середину раковины. Смычная линия у луночек прямая, с вентральным наклоном, а в передней половине раковины слегка волнистая и отогнута дорсально; передняя линия интрапликатная.

Брюшная створка сильно выпуклая. Макушка острая и слабо загнутая, на ее дорсальной стороне расположен дельтирий, а на верхушке маленыкий форамен. По бокам макушки развиты узкие луночки. Боковые части створки вогнутые, каждая имеет до трех слабых ребер.

Спинная створка слабо выпуклая. Синус начинается почти от макушки, неглубокий, расширяющийся кпереди, в середине несет ребровозвышение.

Р а з м е р ы, $м м$

Экземпляр
$\mathrm{Br} 3749$
$\mathrm{Br} 3750$
$\mathrm{Br} 3776$

$\begin{array}{cr}\text { Длина } & \text { Наибольшая } \\ 2,7 & 2,0 \\ 2,2 & 1,7 \\ 2,1 & 1,8\end{array}$

С равнени е. Описанный новый вид является непосредственным предком вида $P$. bicarinata. Отличается от последнего лишь более ребристыми боковыми частями раковины. Отметим, что разграничение видов или подвидов в эволюционных рядах у брахиопод весьма условное (см. также Ziegler, 1966; Williams, 1951). В данном случае это хорошо видно на экземплярах из скв. Кальвария (табл. II): раковина $\mathrm{Br} 3775$ с глубины 769,2 м - типичный $P$. bicarinata; раковины $\mathrm{Br} 3744-3748$ с глубины 775,0 м - уже переходные к $P$. carinata, но относятся еще к $P$. bicarinata. Раковина $\mathrm{Br} 3776$ с глубины 797,6 м (экземпляр наилучшей сохранности) найдена в интервале, содержащем уже ребристые рако- 
внны. Такие же ребристые экземпляры, как $\mathrm{Br} 3749$ и 3750 , хотя, может быть, не со столь ярко выраженными ребрами, встречены в интервале 234,0 -243,6 м скв. Икла. Из последних выбран и голотип описанного вида. Новый вид внешне исключительно похож на «Zygospira» aff. paupera (Boucot and Johnson, 1967, p. 1228, pl. 166, fig. 22-27) из вероятного венлока или даже верхов лландовери (см. Berry and Boucot, 1970 , p. 161), но, судя по краткой характеристике этой формы, у него иное внутреннее строение брюшной створки.

Р аспростр анение. Эстония, венлок, парамаяская пачка яаниского горизонта $\left(\mathrm{J}_{1} \mathrm{P}\right)$; Литва, венлок, яаниский горизонт $\left(\mathrm{J}_{1}\right)$.

Местон ахождения. Скв. Кальвария, интервал глубин 710,7243,55 м. Скв. Кальвария, интервал глубин 793,0-801,3 м.

\section{Род Dayia Davidson, 1881}

Т и по во й в ид: Terebratula navicula Sowerby, 1839.

\section{Dayia bohemica Bouček, 1940}

Табл. III, фиг. $1-3$; табл. IV, фиг. $1-11$; рис. 3

Dayia navicula: Рыбникова, 1967, с. 211, табл. 24, фиг. 10, поп фиг. 11.

Голотип. См. Bouček 1941, Taf. 2, Abb. 1, rechts.

О пи сание. Раковина маленьких размеров, двояковыпуклая, с более высокой брюшной створкой, гладкая. Очертание раковины субпентагональное, наибольшая ширина приходится на заднюю половину раковины. Смычная линия створок отогнута по бокам дорсально, у переднего края варьирует от сулькатной до интрапликатной.

Макушка брюшной створки острая, сильно загнутая, слепка нависающая над спинной; форамен рудиментарный. Створка имеет уплощенные, сильно наклонные боковые части и выпуклый срединный киль в примакушечной части. Киль расширяется, меняя форму в передней половине створки от плоского до вогнутого (в поперечном сечении); в середине несет слабое ребрышко. Крючкообразные зубы опираются на стенки створки, их концы направлены друг ж другу и слегка загнуты, от края створки отделены неглубоким желобком (табл. IV, фиг. 7, 9). Примакушечная часть и середина створки утолщены. На внутренней поверхности видны расходящиеся отпечатки дидукторов. Эти отпечатки разделены опереди выступающим валиком, несущим отпечатки аддукторов. Последние могут быть выражены в виде нескольких мелких валиков (габл. IV, фиг. 9-11).

Спинная створка слабо выпукла толыко в постеролатеральной области. Остальную часть створки занимает синус, который мелким желобком начинается от макушки и резко расширяется около середины створки. Бока синуса плавно переходят в выпуклые части створки; на дне синуса просматривается треугольное (в поперечном сечении) выпуклое возвышение, повторяющее очертание расширенной части синуса. Зуб̆ные ямки окружены с внутренней стороны и снизу изогнутыми утолшениями - раздельной замочной пластиной, а с внешней стороны стенкой створки. К этим же различной формы утолщениям прикреплены тонкие и слегка расходящиеся кпереди круральные пластины (табл. IV, фиг. 6). Нототириальная полость обычно полая, и утолщения, окружающие зубные ямки, сливаются с четким длинным срединным валиком 


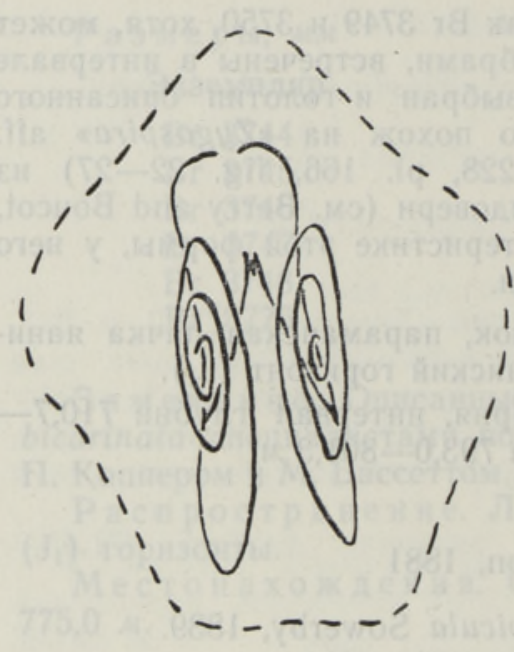

Р а з м е ры, $M M$

Экземпляр

$\begin{array}{ll}\mathrm{Br} & 3722 \\ \mathrm{Br} & 3721 \\ \mathrm{Br} & 3723 \\ \mathrm{Br} & 3724 \\ \mathrm{Br} & 3725 \\ \mathrm{Br} & 3726 \\ \mathrm{Br} & 3727 \\ \mathrm{Br} & 3728 \\ \mathrm{Br} & 3729 \\ \mathrm{Br} & 3730\end{array}$

(табл. IV, фиг. 5). У одного экземпляра ( $\mathrm{Br} 3734)$ нототириальная полость была заполнена толстым двухлопастным замочным отростком. Аддукторное поле выражено слабо. Вершины конусов спиралей ручного аппарата направлены латерально, число оборотов - три; югум расположен в середине, его строение не совсем ясно (рис. 3).

Рис. 3. Схема строения ручного аппарата у вида Dayia bohemica. По раковинам $\mathrm{Br} 3741$ и 3742 , скв. Дубовское, глуб. 1225,5 м.

С равнение и замеч ания. По мнению Буко (Boucot, 1975, p. 138,170$)$, род Dayia происходил от венлакского рода Protozeuga и его распространение связано с лудловом (вид D. navicula) и даунтоном (вид $D$. bohemica с вероятным синонимом D. tenuisepta Shirley, nomen nudum). Это согласуется достаточно хорошо и с тем, что в основном даунтонские представители данного рода из Подолии, Богөмии, а также

\section{ТАБЛИЦА I.}

$a$ - вид с вентральной стороны, $b-$ вид с дорсальной стороны, $d-$ вид сзади, $e-$ вид спереди, $f-$ вид сбоку. Увеличение, $\times 6$. Cyclospira circularis sp. nov., лландовери скв. Икла, 1 - раковина $\mathrm{Br} 3753$, глуб, 393,95 м. 2-4- раковины $\mathrm{Br} 3754,3755$ и 3756 , глуб. 372,45 м. 5, 6 - внутреннее строение спинных створок $\mathrm{Br} 3758$ (глуб. 376,5 м)' и $\mathrm{Br} 3759$ (глуб, 388,55 м), 7 - внутреннее строение брюшной створки $\mathrm{Br} 3757$, глуб. 388,55 м. Dayia navicula (Sow.), лудлов скв. Вентспилс. 8 - раковина $\mathrm{Br} 3777$, глуб. 513,4 м.

\section{ТАБЛИЦА II.}

$a-$ вид с вентральной стороны, $b-$ вид с дорсальной стороны, $d-$ вид сзади, $e-$ вид спереди, $f-$ вид сбоку. Увеличение, $\times 6$.

Protozeuga bicarinata (Vern.), венлок скв. Кальвария. 1 - раковина $\mathrm{Br} 3775$, глуб. 769,2 м. 2 -6 - раковины $\mathrm{Br} 3744,3745,3746,3747$ и 3748 , глуб. 775,0 м,

Protozeuga carinata sp. nov., венлок скв. Кальвария и Икла. 7 - раковина $\mathrm{Br} 3776$, скв. Кальвария, глуб. 797,6 м. 8,9 - раковины $\mathrm{Br} 3749$ (голотип) и 3750 , скв. Икла, глуб. $240,85 M$.

Eocoelia angelini (Lindström), венлок клиффа Ундва. 10 - раковина $\mathrm{Br} 3763$. 
ТАБЛИЦА I
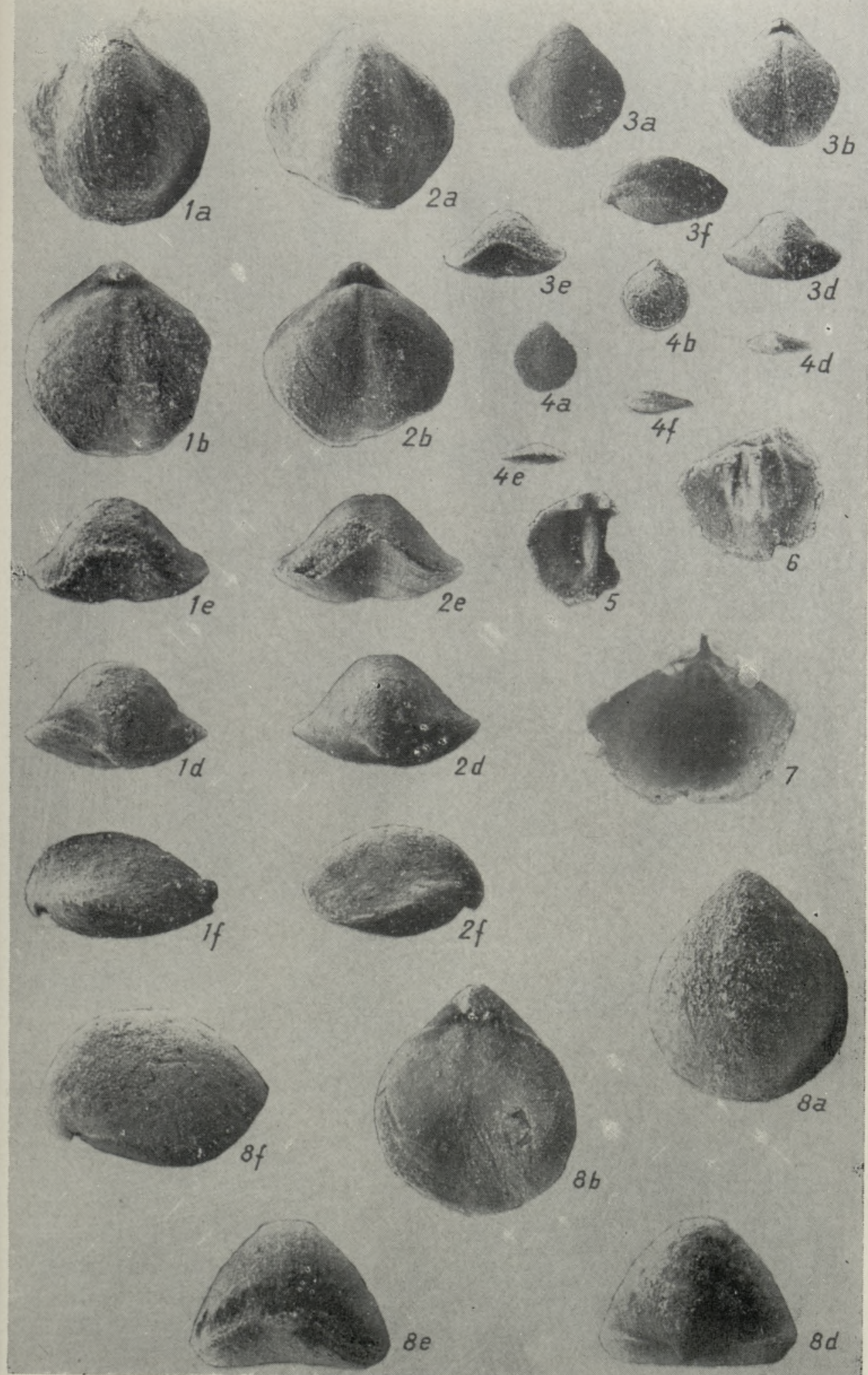

$8 d$ 


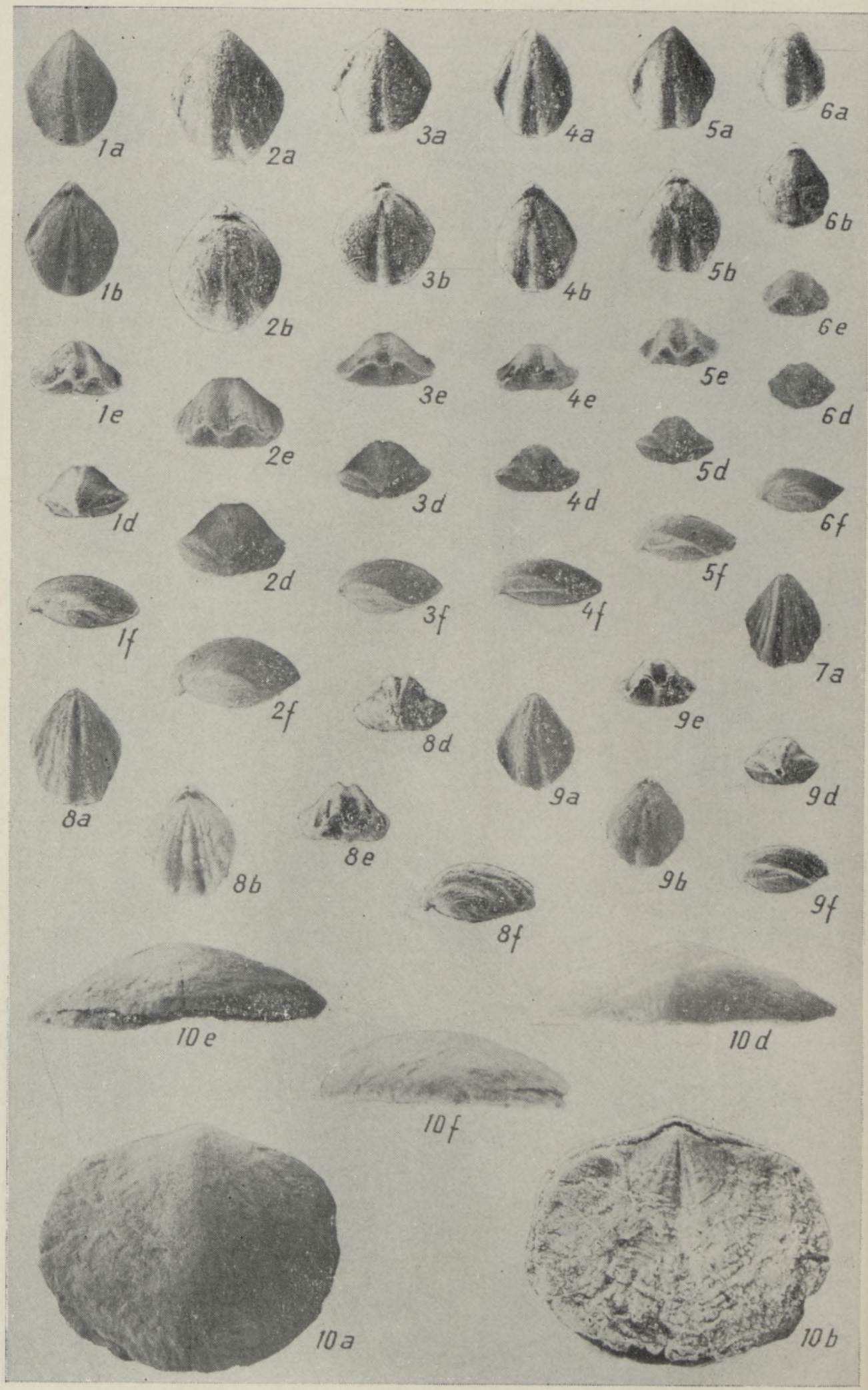


ТАБЛИЦА III

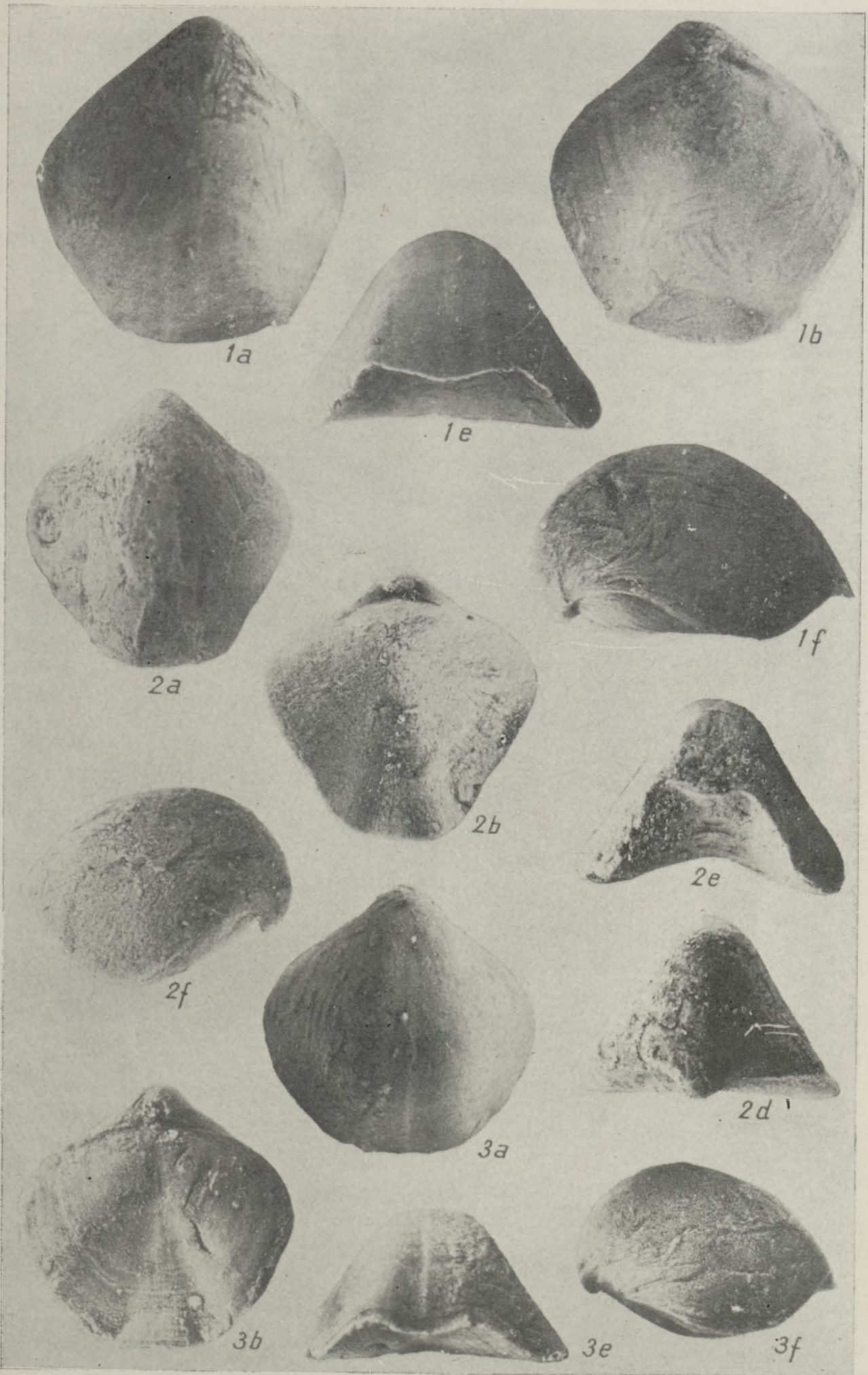




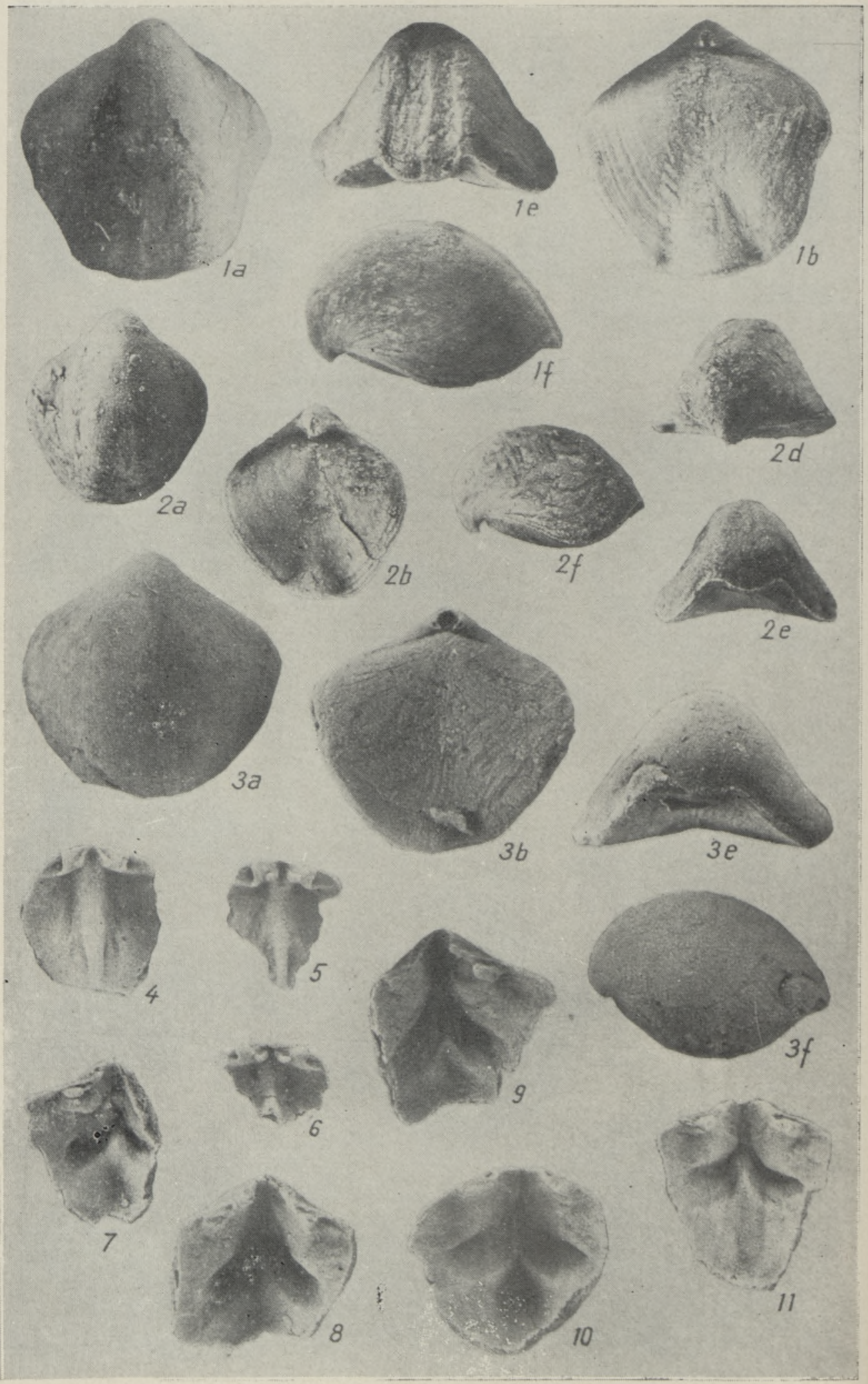


с о-ва Готланд более вытянуты в ширину и имеют меньшую изогнутость (incurvature) брюшной створки, чем английские в лудлове (см. Tucker, 1968). Описанный нами материал явно отличается от типовой серии D. navicula из лудлова Англии. Для наших экземпляров характерны меньшая изогнутость брюшной створки, более четко выраженное пентагональное очертание и приуроченность наибольшей ширины к задней половине створки. Эти же признаки сближают их больше всего с даунтонскими представителями рода, т. е. с видом D. bohemica sensu Boucot.

Р асл ростр анени е. Эстония, даунтон, эйгуские слои каугатумаского горизонта $\left(\mathrm{K}_{3} \mathrm{bA}\right)$; Латвия, Литва и Калининградская область, даунтон, каугатумаский и курессаареокий $\left(\mathrm{K}_{3} \mathrm{~b}, \mathrm{~K}_{3} \mathrm{a}\right)$ горизонты.

Местонахождения.Скв. Дубовское, интервал глубин 1018,51269,7 м. Скв. Кункояй, глубина 1003,4 м. Скв. Эзере, интервал глуб́ин 930,2 -979,0 м. Скв. Каугатума, интервал глубин 16,25-19,0 м.

\section{Dayia navicula (Sowerby, 1839)}

Табл. I, фиг. 8

Dayia navicula: Рыбникова, 1967, с. 211 , табл. 24, фиг. 10, поп фиг. 11. Dayia navicula navicula: Tucker, 1968, p. 614, pl. 118 (синонимика).

Неотип. Раковина GSM 103291 (Geological Survey Museum; Tucker, 1968, pl. 118, fig. 2).

C р а внение и 3 амеч ания. Экземпляры D. navicula наилучшей сохранности найдены из лудлова скв. Вентспилс. Они отличаются от экземпляров даунтонокого вида $D$. bohemica большей изогнутостью брюшной створки, менее дифференцированными килөм и синусом в передней части раковины, а также более срединным расположением наибольшей ширины.

Р а сп р ост р нен и е. Латвия, Литва и Калининградская область, лудлов, паадлаский горизонт $\left(\mathrm{K}_{2}\right)$.

Местон ахождения. Скв. Вентспилс, интервал глубин 512,0630,6 м. Скв. Видукле, интервал глубин 1240,95-1256,40 м. Скв. Дубовское, интервал глубин 1297,2-1310,5 м.

\section{ТАБЛИЦА III.}

$a-$ вид с вентральной стороны, $b-$ вид с дорсальной стороны, $d-$ вид сзади, $e-$ вид спереди, $f-$ вид сбоку. Увеличение, $\times 6$.

Dayia bohemica Bouček, даунтон скв. Дубовское и Кункояй. 1 - раковина $\mathrm{Br} 3722$, скв. Дубовское, глуб. 1146,0 м. 2 - раковина Вr 3721, скв. Кункояй, глуб. 1003,4 м. 3 - раковина $\mathrm{Br} 3723$, скв. Дубовское, глуб. 1225,5 м.

\section{ТАБЛИЦА IV.}

$a-$ вид с вентральной стороны, $b-$ вид с дорсальной стороны, $d-$ вид сзади, $e-$ вид спереди, $f-$ вид сбоку. Увеличение, $\times 6$.

Dayia bohemica Bouček, даунтон скв. Дубовское и Эзере. 1,2 - раковины $\mathrm{Br} 3724$ и 3725 , скв. Дубовское, глуб. 1225,5 м. 3 - раковнна $\mathrm{Br} 3730$, скв. Эзере, глуб. 978,2 м. 4 - внутреннее строение спинной створки $\mathrm{Br} 3731$, скв. Эзере, глуб. 976,3 м. 5, 6 - внутреннее строение спинных створок $\mathrm{Br} 3732$ (глуб. 1103,0 м) и $\mathrm{Br} 3733$ (глуб. 1154,5 м), скв. Дубовское. $7-9$ - внутреннее строение брюшных створок Br 3736 (глуб. 1218,3 м), $\mathrm{Br} 3735$ (глуб. 1154,5 м) и Вr 3737 (глуб. 1160,0 м), скв. Дубовское. 10, 11 - внутреннее строение брюшных створок $\mathrm{Br} 3738$ (глуб. 976,0 м) и $\mathrm{Br} 3740$ (глуб. 976,3 м), скв. Эзере. 
Семейство Anoplothecidae Schuchert, 1894

Подсемейство Coelospirinae Hall et Clarke, 1894

Род Coelospira Hall, 1863

Т ипо в ой в ид: Leptocoelia concava Hall, 1857.

Coelospira pusilla (Hisinger, 1837)

Coelospira baltica: Рыбникова, 1967, с. 209, табл. 24, фиг. 8, 9. Coelospira pusilla: Bassett and Cocks, 1974, p. 32, pl. 9, fig. 4 (полная синонимика).

3 а меч ание. Недавно опубликованный лектотип вида C. pusilla (см. Bassett and Cocks, 1974) и его описание (Boucot and Johnson, 1967, p. 1237 , pl. 165 , fig. $16-28,34$ ) не оставляют сомнения в том, что виды C. baltica и C. pusilla идентичны.

Семейство Leptocoeliidae Boucot et Gill, 1956

Род Eоcoelia Nikiforova, 1961

Т ипово й в ид: Atrypa hemisphaerica Sowerby, 1839.

Eocoelia angelini (Lindström, 1861)

Табл. II, фиг. 10

Eocoelia angelini: Bassett and Cocks, 1974, p. 32, pl. 9, fig. 5-9 (полная синонимика).

Л ектотил. Спинная створка $\mathrm{Br} 102368$ (Naturhistoriska Riksmuseet, Stockholm; Bassett and Cocks, 1974, pl. 9, fig. 6).

О пис ание. Раковина средних размеров, вогнуто-выпуклая, слабо ребристая толыко в примакушечной части. Очертание субовальное, вытянутое в ширину. Линии нарастания выражены в виде низких концентрических ступенек.

Брюшная створка слабо выпуклая, маленькая макушка и срединный киль расположены в задней части створки. Наивысшая точка приурочена к середине створки.

Спинная створка умеренно вогнутая, макушка острая и маленькая. Узкий синус отчетливо выражен только в примакушечной части створки.

Р а $з$ м е ры, мм

$\begin{array}{ccc}\text { Экземпляр } & \text { Длина } & \text { Наибольшая ширина } \\ \operatorname{Br} 3763 & 7,5 & 9,5\end{array}$

С равнени е. Определения описанных экземпляров даны А. Циглером в 1973 г. (устное сообщение) с учетом данных М. Бассетта и J1. Кокса (Bassett and Cocks, 1974).

Р аспростр анение. Эстония, венлок, ниназеская пачка яаниского горизонта $\left(\mathrm{J}_{1} \mathrm{~N}\right)$.

Местон ахождения. Обнажения на клиффах Ундва (1 раковина) и Суурику (1 раковина) о-ва Сааремаа. 


\section{К распространению изученных брахиопод}

Ревизия показала, что все четыре до сих пор известных вида Dayiacea из силура о-ва Готланд (Bassett and Cocks, 1974) встречаются и в силуре Прибалтики. В связи с этим интересно сравнить распространение их в разрезах названных двух местонахождений.

Род Cyclospira широко распространен в ордовике северного полушария. Его переход в силур известен пока только в двух местах: на о-ве Антикости и в Эстонии (из верхнего ордовика Эстонии описан вид C. levisulcata; см. Рыммусокс, 1964).

Род Protozeuga известен в венлоке Англии и только в мергелях Мульде о-ва Готланд. Интервал распространения его в скв. Кальвария находится непосредственно ниже интервала, соответствующего слоям Халла-Мульде (Сарв, 1973). Более раннее его появление в скв. Кальвария и Икла согласуется достаточно хорошо с морфологическими изменениями, на основе которых и установлен эволюционный ряд.

В очерке о роде Dayia (Boucot, 1975) его различным подвидам или видам дано хронологическое объяснение. В связи с этим вполне возможны находки как $D$. navicula, так и $D$. bohemica на о-ве Готланд, поскольку, по имеющимся данным, род Dayia распространен там на границе лудлова и даунтона (слои Хемзе и Эке).

Находки Eocoelia angelini-последнего вида из эволюционного ряда рода Eocoelia (Ziegler, 1966; Bassett and Cocks, 1974), обнаруженные в ниназеской пачке яаниского горизонта, хорошо согласуются с имеющимися корреляциями силурийских разрезов островов Сааремаа и Готланд.

Указанный М. В. Рыб̆никовой (1967) интервал раопространения вида Coelospira baltica $(=C$. pusilla $)$ в скв. Пилтене $-606,8-630,0$ м сопоставим (по данным Д. Кальо) с низами курессаареского горизонта $\left(\mathrm{K}_{3} \mathrm{a}\right)$. Интервал распространения остатков этого вида в скв. Эзере 1056,0 - 1802,0 м (по тем же данным) занимает пограничное между лудловом и даунтоном положение, причем имеющаяся палеонтологическая карактеристика по другим ископаемым не позволяет определить стратиграфический возраст этого интервала однозначно. Имея в виду предыдущую датировку и даунтонский возраст (слои Эке, Бурсвик, Хамра и Сундре по Bassett and Cocks, 1974) вида C. pusilla на о-ве Готланд, вполне оправданно проведение начала даунтона в разрезе скв. Эзере под интервалом распространения C. pusilla.

\section{ЛИТЕРАТУРА}

Ры бников а М. В. 1967. Описание брахиопод. В кн.: Ульст Р. Ж. (ред.) Стратиграфия, фауна и условия образования силурийских пород Средней Прибалтики. Рига.

Р ы ы у со к с А. 1964. Некоторые брахиоподы из ордовика Эстонии. Тр. по геологии, II. Уч. зап. Тартуск. гос. ун-та, № 153.

С а р в Л. 1973. Расчленение силура в разрезе скважины Калвария по остракодам. Изв. АН ЭССР, Хим. Геол., 22, № 1.

B a s s et t, M. G., C o cks, L. R. M. 1974. A review of Silurian brachiopods from Gotland. Fossils and Strata, No. 3.

B erry, W. B. N., B o u cot, A. J. (ed.) 1970. Correlation of the North American Silurian Rocks. Geol. Soc. of America. Spec, Paper, 102.

B o ucot, A. J. 1975. Evolution and extinction rate controls. Developments in Paleontology and Stratigraphy, 1. Amsterdam-Elsevier.

Boucot, A. J., Johnson, J. G. 1967. Species and distribution of Coelospira (Brachiopoda). J. Paleontology, 41, No. 5. 
B o uč e k, B. 1941. Uber die Variabilität der Brachiopoden Dayia navicula (Sow.) und Cyrtia exporrecta (Wahl.) und über die Anwendung von variations-statistischen Methoden in der Paläontologie. Mitteilungen der Tschech. Akad. der Wissensch.

M o ore, R. G. (ed.). 1965. Treatise on Invertebrate Paleontology, Part H, Brachiopoda. Lawrence.

Tucker, E. V. 1968. The atrypidine brachiopod Dayia navicula (J. de Sowerby). Paleontology, 11, pt. 4.

T we n h of el, W. H. 1927. Geology of Anticosti Island. Canada Geol. Surv. Mem., 154, No. 135.

Wi 11 i a ms, A. 1951. Llandovery brachiopods from Wales with special reference to the Llandovery district. Quart. J. Geol. Soc. London, 107, No. 425.

Ziegler, A. M. 1966. The Silurian brachiopod Eocoelia hemisphaerica (J. de Sowerby) and related species. Palaeontology, 9, pt. 4.

Ннститут геологии

Академии наук Эстонской ССР
Поступила в редакцию 23/IV 1976

M. RUBEL

\section{BALTIKUMI SILURI DAYIACEA (BRACH.) REVISJON}

Käesolevaks ajaks on Baltikumi silurist teada 7 ülemsugukonda Dayiacea kuuluvat liiki. Neist kaht - Cyclospira circularis't ja Protozeuga carinata't - kirjeldatakse uute liikidena, kolm - Protozeuga bicarinata, Dayia bohemica ja Eocoelia angelini - on vaadeldavas regioonis esmasleiud ning kahe - Dayia navicula ja Coelospira pusilla (sünonüümnimetus $C$. baltica) - mahtu on revideeritud.

\section{RUBEL}

\section{REVISION OF SILURIAN DAYIACEA (BRACH.) FROM THE NORTH-EAST BALTIC}

The following Dayiacea are described or discussed.

Cyclospira circularis sp. $\mathrm{n}$. from the Middle Llandovery of Estonia closely resembles C. anticostiana (Twenhofel, 1927), but differs from it in developing a more transverse outline and a shallower pedicle valve sulcus.

Protozeuga bicarinata (Vern.) from the Wenlockian of Lithuania has weakly developed lateral ribs on both valves. It is also stratigraphically older than the topotypes of the species.

Protozeuga carinata sp. n. from the Wenlockian of Lithuania and Estonia (stratigraphically older than $P$. bicarinata) has already relatively strong lateral ribs. Thus the two species of Protozeuga are here recognized as the evolving species of the same lineage.

Specimens of Dayia from the Ludlovian and Downtonian of Lithuania, Latvia, Estonia and Kaliningrad District may be classified in the same way (see also Boucot, 1975). D. navicula is related to the Ludlovian; it possesses a more elongated outline and a stronger incurvature than the Downtonian D. bohemica.

Coelospira baltica (Rybnikova, 1967) from the Downtonian of Latvia is considered as a younger subjective synonym to $C$. pusilla (Hisinger, 1837). given.

A description of two specimens of Eocoelia angelini from the Wenlockian of Estonia is 